\author{
KS. KRZYSZTOF O. POKORSKI \\ Wydział Administracji i Nauk Społecznych \\ Wyższa Szkoła Administracji Publicznej w Szczecinie \\ ORCID: 0000-0003-3734-1573
}

\title{
WOTUM SĘDZIOWSKIE ELEMENTEM KONSTYTUUJACCYM IUDICIUM. WOTUM JAKO AKT WŁADZY SECDZIOWSKIEJ I JEGO UWARUNKOWANIA PSYCHOLOGICZNE
}

Treść: Wstęp. - 1. Wotum sędziego jako akt władzy sędziowskiej. - 2. Psychologiczne uwarunkowania wotum sędziowskiego. - Zakończenie.

\section{Wstęp}

Kanoniczne postępowanie sądowe - iudicium, jest szeregiem ściśle uporządkowanych i koniecznych do wykonania czynnościi. Celem tego postępowania jest ustalenie, uporządkowanie, rozpoznanie i rozstrzygnięcie, zgodnie z przepisami prawa, zgłoszonych przez strony roszczeń ${ }^{2}$. Jednym z elementów iudicium jest osoba sędziego kościelnego, który po rozpoznaniu sprawy dąży do jej rozstrzygnięcia ${ }^{3}$. Po wypełnieniu wszystkich przewidzianych prawem czynności sędzia

\footnotetext{
${ }^{1}$ Niniejszy artykuł jest częścią rozważań, które autor podjął w swojej pracy doktorskiej pt.: Votum separatum w kanonicznym procesie o nieważność małżeństwa. Kompleksowo na temat iudicium por. M. Greszata, Iudicium cum principiis, Kodeksowa weryfikacja wybranych zasad procesowych w kanonicznych sprawach o nieważność mał̇̇eństwa, Lublin 2008, s. 77-172.

${ }^{2}$ Por. A. DzIĘGA, Strony sporu w kanonicznym procesie o nieważność małżeństwa, Warszawa 1994, s. 37.

${ }^{3}$ Por. M. Greszata, Iudicium cum principiis, s. 405.
} 
kończy postępowanie sądowe decyzją w sprawie, która wydawana jest w formie wyroku ${ }^{4}$.

Zanim jednak sędzia wyda wyrok musi przeanalizować dowody zebrane w sprawie i sformułować osobisty wniosek - wotum, które zostanie poddane dyskusji sędziowskiej. Argumenty, które sędzia podaje w wotum, a będące wyrazem poszukiwania prawdy obiektywnej oraz uzyskania pewności moralnej, staną się podstawą wyroku. W ten sposób wotum sędziowskie staje się elementem konstruującym iudicum.

Zagadnienie wotum sędziowskiego jest bardzo szerokie i wymaga bliższej analizy, dlatego całość rozważań stanowią dwa artykuły podejmujące tę kwestię. Niniejszy artykuł prezentuje wotum jako akt władzy sędziowskiej i jego uwarunkowania psychologiczne. W kolejnym szczegółowej analizie zostało poddane pojęcie wotum sędziowskiego oraz jego relacja do prawdy obiektywnej i pewności moralnej.

\section{Wotum sędziego jako akt władzy sędziowskiej}

Prawodawca kościelny stwierdza, że biskup diecezjalny jest sędzią I instancji we własnej diecezji i dla wszystkich spraw ${ }^{5}$. Władzę sądową może on wykonywać osobiście lub poprzez mianowanych przez siebie sędziów ${ }^{6}$. W ten sposób określona została kompetencja do wydawania aktów władzy sędziowskiej w prowadzonych sprawach. Należy więc ukazać, jakie akty sądowe stanowi sędzia podczas trwania procesu. Ważne jest także ukazanie osobistego wotum sędziego wśród innych aktów władzy sędziowskiej.

\footnotetext{
${ }^{4}$ Por. A. DzięGA, Strony sporu, s. 38.

${ }^{5}$ Por. K. Pokorski, Władza sądownicza $w$ strukturze władzy kościelnej, w: Człowiek - Rodzina - Prawo, red. P. Telusiewicz, Nr 6(15), data wydania: 30 czerwca 2013 roku, s. 16-21, http://www.kul.pl/files/192/public/NUMER_6_2013.pdf.; Tenże, Źródła władzy sądowniczej biskupa, w: Człowiek - Rodzina - Prawo, red. P. Telusiewicz, Nr 11, data wydania: 30 listopada 2013 roku, s. 25-31, http://www.kul.pl/ files/192/public/NUMER_11_2013.pdf.

${ }^{6}$ Por Codex IURIs CANONICI auctoritate Ioannis Paulii PP. II promulgatus, AAS 75 (1983), pars II, s. 1-317, przekład polski zatwierdzony przez Konferencję Episkopatu Polski, Poznań 2008, c. 1419 \$ 1 i c. 1421 \$1, (dalej CIC).
} 
Sędzia kościelny od momentu formalnego zaistnienia sporu, aż do jego ostatecznego rozstrzygnięcia, odpowiada za właściwe i zgodne $\mathrm{z}$ prawem prowadzenie procesu ${ }^{7}$. Jednym $\mathrm{z}$ wymiarów prowadzonej sprawy jest tworzenie i gromadzenie właściwych dokumentów. Zalicza się do nich akta sprawy i akta procesu. Aktami sprawy są te dokumenty, które dotyczą merytorycznej strony procesu. Ich wartość dowodowa jest niezależna od trwania procesu. Jeśli postępowanie zostaje umorzone, akta sprawy nie tracą na wartości. Są to między innymi skarga powodowa, zeznania stron i świadków, opinie biegłych czy orzeczenia sądowe. Natomiast akta procesu dotyczą strony proceduralnej. Potwierdzają one formalną stronę postępowania sądowego i ich ważność dotyczy tego jednego procesu. Są nimi na przykład wezwania sądowe, powiadomienia, ustanowienia terminów sądowych czy odroczenia ${ }^{8}$. Akta sprawy i procesu, są, więc dokumentami, które zostały stworzone podczas procesu, lecz ich źródłem jest decyzja konkretnego sędziego o konieczności ich zaistnienia.

Odmienny charakter od akt sprawy czy procesu mają akty sędziowskie, które są wyrazem władzy sędziego. Są one decyzją dotyczącą konkretnych kwestii lub czynności, które organizują postępowanie sądowe. Różnica, więc polega na zrozumieniu aktu jako woli i decyzji sędziego. Dotyczą one dwóch faz procesowych, czyli rozpoznawania sprawy i jej rozstrzygnięcia.

Podczas rozpoznawania sprawy akty sędziowskie dotyczą decyzji organizujących postępowanie sądowe i są wyrażone w postaci dekretów silnych lub zwykłych. Dekrety zwykłe (proste) mogą być zmieniane, uzupełniane lub anulowane, a sędzia może do nich podczas procesu powracać. Ich zadaniem jest uporządkowanie postępowania procesowego a nie zamknięcie jakiejś istotnej kwestii postępowania9

\footnotetext{
${ }^{7}$ Por. A. DzIĘGA, Władza sędziego kościelnego, w: Urzędy sądowe - władza i służba. Materiały z ogólnopolskiego spotkania pracowników sądownictwa kościelnego w Gródku nad Dunajcem w dniach 11-12 października 2004 roku, red. T. Rozkrut, Tarnów 2005, s. 26.

${ }^{8} \mathrm{Na}$ temat akt sprawy i procesu szczegółowo por. T. Rozkrut, Tytuł VII: Dowody, w: Komentarz do Instrukcji procesowej, s. 229-295.

${ }_{9}^{9}$ Por. M. Greszata, Iudicium cum principiis, s. 388.
} 
Dekrety te mogą przybrać formę prostą decyzji sędziego, czyli na przykład sądowa notatka, poprawka na marginesie. Może także mieć formę uroczystą, którą stanowi właściwy formularz i urzędowa forma decyzji ${ }^{10}$.

Dekrety silne (mocne), podejmowane podczas rozpoznawania sprawy, są decyzjami, które w istotny sposób zmieniają relacje w procesie. Zamykają one konkretny etap postępowania procesowego. Po ich wydaniu ani sędzia, ani żadna inna osoba, nie może powrócić do sprawy, której dotyczył dekret. Odstępstwa od tej zasady, w wyjątkowych sytuacjach określa samo prawo ${ }^{11}$. Dekret silny nie tylko definitywnie zamyka określony etap procesu, ale także konieczny jest do tego, aby móc rozpocząć kolejny. Przed wydaniem dekretu silnego nie można podejmować decyzji dotyczących czynności w kolejnym etapie, a po jego wydaniu nie powraca się do etapu poprzedniego ${ }^{12}$.

Istotnym zadaniem sędziego kościelnego jest rozstrzyganie spraw $^{13}$. Pośród aktów sędziowskich w tej fazie iudicium rozróżnić możemy cztery jego rodzaje. Są nimi wyrok stanowczy, wyrok przedstanowczy, dekret stanowczy i dekret przedstanowczy.

Dwa pierwsze rodzaje aktów sędziowskich wydawane są w formie wyroku. Pierwszym spośród wymienionych rodzajów aktów sędziowskich jest wyrok stanowczy. Akt ten wydawany jest przez sędziego w sprawie głównej. Decyzja sędziego rozstrzyga spór i kończy postępowanie sądowe w określonej instancji ${ }^{14}$. Drugim rodzajem aktu

\footnotetext{
${ }^{10}$ Por. A. DzIĘGA, Władza sędziego, s. 27; Tenże, Normy Instrukcji Dignitas Connubii w konfrontacji z teoria procesu (zagadnienia wybrane), w: Proces małżeński w świetle Dignitas Connubii - pierwsze doświadczenia, Materiały z ogólnopolskiego spotkania pracowników sądownictwa kościelnego w Gródku nad Dunajcem w dniach 11 i 12 czerwca 2007 roku, red. T. Rozkrut, Tarnów 2008, s. 34-35.

${ }^{11}$ Por. M. Greszata, Kanoniczne procesy małżeńskie, Pomoc dla studentów, Lublin 2007, s. 107.

${ }^{12}$ Por. A. DzIĘGA, Władza sędziego, s. 28.

${ }^{13}$ Por. S. Pikus, Sędzia kościelny w świetle zadań i uprawnień procesowych, Prawo Kanoniczne 45(2002) nr 3-4, s. 273-275.

${ }^{14}$ Por. M. Greszata, Iudicium cum principiis, s. 387.
} 
sędziowskiego jest wyrok przedstanowczy ${ }^{15}$. Decyzja ta rozstrzyga spór nie w sprawie głównej, ale incydentalnej, czyli wpadkowej, jeśli jest ona rozpatrywana $\mathrm{w}$ trybie postępowania procesowego ${ }^{16}$.

Koleje dwa akty sędziowskie to dekrety. Dekret stanowczy wydawany jest w sprawie głównej, procedowanej w trybie administracyjnym. Dekret ten jest aktem II instancji, która zatwierdza wyrok I instancji dotyczący sprawy o orzeczenie nieważności małżeństwa. Decyzja ta wydawana jest w formie dekretu, ponieważ nie jest prowadzone odrębne postępowanie a jedynie następuje zatwierdzenie wyroku I instancji. Różnica między wyrokiem a dekretem stanowczym polega jedynie na trybie postępowania sądowego, gdyż w kwestii formalnej oba te akty są jednakowe. Natomiast dekret przedstanowczy jest rozstrzygnięciem sprawy wpadkowej, jeśli prowadzona była $\mathrm{w}$ trybie administracyjnym ${ }^{17}$.

Szczególnym aktem procesowym, którego autorem jest sędzia, jest jego wotum w sprawie. Wotum jest nie tylko wypełnieniem formalnego wymogu, który stawiany jest przed sędzią. Sędzia kościelny zapoznając się z aktami i dowodami zebranymi w sprawie dąży do odkrycia prawdy obiektywnej oraz zdobycia pewności moralnej ${ }^{18}$. Stąd wotum sędziowskie nie jest tylko dokumentem potwierdzającym dany fakt w procesie czy nadającym bieg procedurze, jak w przypadku dekretów. Jest to wewnętrzna opinia, oparta na zdobytych dowodach i zbudowana w sumieniu. Osobisty wymiar wotum potwierdza fakt, że sędzia sam podpisuje wotum i poza nim nikt nie może nanieść w nim poprawek. Normy procedu-

\footnotetext{
${ }^{15}$ Por. M. Greszata-Telusiewicz, Zasada niepodważalności dekretów i wyroków przedstanowczych $w$ kanonicznym procesie o nieważność matżeństwa, Studia Prawnicze KUL 4(40) 2009, s. 53-65.

${ }^{16}$ Por. A. DzIĘGA, Władza sędziego, s. 28; A. DzIĘGA, Sprawy wpadkowe, publikacja akt, dyskusja sprawy (art. 217 - 245), w: Proces małżeński według Instrukcji Dignitas Connubii, Materiały z ogólnopolskiego spotkania pracowników sądownictwa kościelnego w Gródku nad Dunajcem w dniach 13-14 czerwca 2005 roku, red. T. Rozkrut, Tarnów 2006, s. 113-127.

${ }^{17}$ Por. M. Greszata, Iudicium cum principiis, s. 387.

${ }^{18}$ CIC, c. 1608.
} 
ralne, którym podporządkowane są poszczególne akty sędziowskie nie mają bezpośredniego wpływu na wotum. Choć przyjmuje się pewne zasady redakcyjne wotum, poza nimi sędzia pozostaje wolny w formułowaniu wniosków i argumentów. Wotum sędziowskie jest więc najbardziej osobistym i dowodzącym niezawisłość sędziowską aktem procesowym.

\section{Psychologiczne uwarunkowania wotum sędziowskiego}

Prawodawca kościelny formułując wymagania stawiane sędziom kościelnym wskazuje na kwestie mające charakter personalny. Sędzia musi być człowiekiem o możliwie najgłębszym poczuciu słuszności i sprawiedliwości ${ }^{19}$. Taka postawa sędziego wypływa z poziomu jego wiedzy, nienaruszonej sławy i posiadanych cech osobowości ${ }^{20}$. Istotne jest więc spojrzenie na osobę sędziego przez pryzmat psychologii. Z jednej strony należy zauważyć te cechy, które określają osobowość sędziego i jego predyspozycje do wypełniania władzy sądzenia. Z drugiej zaś, istotnej dla przedmiotu rozważań, trzeba ukazać wszystkie te mechanizmy psychologiczne, które mają wpływ na dokonanie rozpoznania i rozstrzygnięcia sprawy oraz umotywowanie wotum sędziowskiego.

Wobec sędziego kościelnego wymaga się nie tylko odpowiednich kwalifikacji intelektualnych, które gwarantują biegłą znajomość obowiązującego prawa oraz umiejętności jego stosowania, czy doświadczenia prowadzenia spraw sądowych. Istotne są także szczególne predyspozycje psychologiczne i etyczne ${ }^{21}$. To właśnie cechy

\footnotetext{
${ }^{19}$ Por. M. SAfJAn, Etyka zawodu sędziowskiego, w: Ius et Lex. Księga Jubileuszowa ku czci Profesora Adama Strzembosza, red. A. Dębiński, A. Grześkowiak, K. Wiak, Lublin 2002, s. 267.

${ }^{20} \mathrm{CIC}, \mathrm{c} .1421 \S 3$.

${ }^{21}$ Por. A. DzIĘGA, Kanoniczno-prawne i duszpasterskie zadania trybunału diecezjalnego, w: Ius et Lex. Księga Jubileuszowa ku czci Profesora Adama Strzembosza, red. A. Dębiński, A. Grześkowiak, K. Wiak, Lublin 2002 s. 454.
} 
osobowościowe sędziego są pierwszym czynnikiem prawidłowego orzekania w sprawie ${ }^{22}$.

Termin osobowość używany jest dla opisania zorganizowanej struktury cech indywidualnych i sposobów zachowania, które decydują o specyficznych sposobach przystosowania się danej osoby do jej środowiska ${ }^{23}$. W tym kontekście ukazując osobę sędziego kościelnego należy wskazać na ujęcie poznawcze osobowości. W tym ujęciu osobowość jest szczególnym sposobem konstruowania zdarzeń (wytwarzaniem znaczeń), personalnym poziomem integracji zachowania oraz stylem podejmowanych działań. Podejście to koncentruje się na integralnym obrazie własnej osoby. Sposób postrzegania siebie przez daną osobę nadaje znaczenie własnym doświadczeniom, wyznacza własne relacje do świata, oraz jest podstawą podmiotowej kontroli i samoregulacji. Dzięki tym procesom dana osoba może wywierać pożądany wpływ na bieg zdarzeń i zapewnić własnemu zachowaniu odpowiedni poziom jego wewnętrznej integracji ${ }^{24}$.

Sędzia kościelny w toczącym się procesie wielokrotnie dokonuje interpretacji prawa oraz przedstawionych w sprawie dowodów i faktów. Interpretacja wspomniana dokonuje się za pomocą procesów psychicznych, na które wpływ mają cechy charakteru oraz osobowość sędziego. Stąd sposób myślenia sędziego zależy między innymi od jego osobowości ${ }^{25}$. Struktura osobowości sędziego wpływa na poziom zachowania przepisów proceduralnych, kulturę sądzenia oraz treść wydawanych orzeczeń. Decyzje sędziowskie zawierają bowiem subiektywny jego wkład oraz sposób postrzegania i rozumienia świata ${ }^{26}$. Tak rozumiane znaczenie osobowości sędziego kościelnego wypływa

\footnotetext{
${ }^{22}$ Por. Z. Grocholewski, Pewność moralna jako klucz do lektury norm procesowych, Ius Matrimoniale 3(1998), s. 32.

${ }^{23}$ Por. J. Strelau, Z. Pietrasiński, J. Reykowski, Osobowość, w: Psychologia, red. T. Tomaszewski, Warszawa 1976, s. 684.

${ }^{24}$ Por. M. Kofta, D. Doliński, Poznawcze podejście do osobowości, w: Psychologia. Podręcznik akademicki, t. 2: Psychologia ogólna, red. J. Strelau, Gdańsk 2000, s. 561.

${ }^{25}$ Por. I. Andrejew, Rozpoznanie znamion przestępstwa, Warszawa 1968, s. 37.

${ }^{26}$ Por. R. Sobański, Uwagi o tożsamości sędziego kościelnego, Prawo Kanoniczne 45(2002) nr 3-4, s. 11.
} 
z cech, które powinien posiadać. Między innymi są to: umiłowanie prawdy, sprawiedliwość, prawość charakteru, umiejętność logicznego myślenia, sprawność w analizie sytuacji i podejmowaniu decyzji oraz roztropnośćc ${ }^{27}$. Istotne są te cechy osobowościowe, które mają wpływ na gromadzenie, interpretację i ocenę materiału dowodowego zebranego w sprawie oraz formułowanie rozstrzygnięć. Należą do nich: spostrzegawczość, zdolność koncentracji uwagi oraz jej podzielność, wierność i gotowość pamięci, konstruktywna wyobraźnia, wysoki poziom inteligencji, wysoki poziom etyczny i uczciwość połączona z umiejętnością wywierania wpływu na przesłuchiwanych, obiektywizm i bezstronność, przekonanie, że najważniejszą rzeczą jaką się poszukuje jest prawda obiektywna, umiejętność oceny materiału dowodowego, umiejętność panowania nad sobą w czasie przesłuchań (samokontrola emocjonalna), życzliwość i empatia, formułowanie odpowiednich pytań, umiejętność odpowiedniego przygotowania się do przesłuchania ${ }^{28}$.

Osobiste przymioty i cechy sędziego mają wpływ na jego postępowanie i wnioskowanie w danej sprawie. Z psychologicznego punktu widzenia istotnym dla rozpoznania sprawy są trzy elementy. Pierwszym z nich jest etap dowodzenia, w którym tworzy się psychologiczna relacja między sędzią a świadkami lub innymi środkami dowodowymi. Następnym elementem jest wnioskowanie, w którym sędzia w swoim umyśle dokonuje oceny i nadaje znaczenia zebranym dowodom w sprawie. Kolejnym elementem jest moment podjęcia przez sędziego decyzji rozstrzygającej, która jest wynikiem psychologicznego i logicznego wnioskowania sędziego.

W kanonicznym procesie o nieważność małżeństwa istotne jest to, czy strony są w stanie umotywować swoje twierdzenie odpowiednimi

\footnotetext{
${ }^{27}$ Por. A. DzIĘGA, Kanoniczno-prawne i duszpasterskie zadania trybunału diecezjalnego, s. 454.

${ }^{28}$ Por. M. Ciosek, Psychologia sądowa i penitencjarna, Warszawa 2001, s. 97-98; Z. Czeczot, Kryminalistyczna problematyka osobowych źródeł dowodowych, Warszawa 1976, s. 45-49; W. KoŁA KowsкA, B. LACH, Psychologiczne determinanty zeznań świadków i osób składających wyjaśniania, Szczytno 2002, s. 3.
} 
dowodami. Sędzia kościelny, aby uznać dane twierdzenia za udowodnione, w swoim umyśle postępuje według pewnego schematu. Najpierw sędzia musi sobie jasno określić te kwestie, które wymagają ustalenia, usuwając to wszystko, co jest dla sprawy nieistotne i poboczne. Następnie sędzia powinien ustalić źródła środków dowodowych oraz rozważyć czy dane dowody mogą być przyjęte w sprawie. Następnie działając zgodnie z prawem tak przeprowadzić dany dowód, aby wystarczająco naświetlił badaną kwestię. Chodzi o takie wydobycie prawdy, aby w osobowości sędziego nie pozostała żadna wątpliwość o danej kwestii. Kolejnym etapem jest ocena dowodów, która wymaga od sędziego nie tylko wiedzy teoretycznej, ale także logicznego wnioskowania dokonanego w umyśle. Ostatnim elementem jest dokonanie w oparciu o przeprowadzoną ocenę ustaleń faktycznych, czyli rozstrzygnięcia danej kwestii ${ }^{29}$.

Psychologia wskazuje, że w etapie dowodzenia ważną rolę posiada także doświadczenie sędziego. W każdej sprawie sędzia musi przyjąć różnorodne informacje oraz dokonać procesów myślowych opartych na zdobytych informacjach. Doświadczenie sprawia, że wiele $\mathrm{z}$ informacji nie jest dla sędziego nowością, gdyż niektóre ogólne zdarzenia i fakty powtarzają się w różnych procesach, ponieważ są oparte na tym samym tytule dowodzenia. Ważne jest więc zachowanie przez sędziego umiejętności spostrzegania tego, co w danej, konkretnej sprawie jest istotne ${ }^{30}$. Wynika to z psychologicznego procesu spostrzegania. Każdy sędzia podlega specyficznym procesom organizacji (porządkowania) i selekcji (wyodrębniania). Sędzia nie rejestruje wszystkich bodźców, lecz te, które mają według jego oceny jakieś znaczenie ${ }^{31}$. Stąd bardzo ważne dla rozstrzygnięcia sprawy jest kompleksowe i wyczerpujące zebranie materiału dowodowego

\footnotetext{
${ }^{29}$ Por. P. Hofmański, S. ZABŁocki, Elementy metodyki pracy sędziego $w$ sprawach karnych, Zakamycze 2006, s. 138.

${ }^{30}$ Por. Z. WŁodarski, A. Matczak, Wprowadzenie do psychologii, Podręcznik dla nauczycieli, Warszawa 1992, s. 183-184.

${ }^{31}$ Por. J. STANik, Wybrane problemy zeznań świadków, w: Wybrane zagadnienia psychologii dla prawników, red. M. Lubelski, J. Stanik, L. Tyszkiewicz, Warszawa 1986, s. 230.
} 
w formie pisemnej lub materiału, który można odtworzyć. Związane jest to z psychologiczną zdolnością do przechowywania doświadczeń w pamięci, która jest bardzo zindywidualizowana i może mieć charakter wybiórczy ${ }^{32}$.

Wspomniane wyżej doświadczenie i cechy sędziego pomagają mu w relacjach, które tworzą się między nim i innymi osobami w sprawie. Bez względu na to, czy sędzia osobiście gromadzi dowody, czy wnioskuje na podstawie zebranego materiału dowodowego, tworzą się psychologiczne relacje, które wpływają na osobę sędziego. Pierwsza z nich to sytuacja kooperacji, czyli taka, w której cele sędziego i strony lub świadka są zbieżne, przez co nie powstają negatywne odczucia i emocje. Sędzia w takiej sytuacji nie podlega psychicznym naciskom i jego ocena pozostaje wolna od czynników negatywnych.

Inaczej jest, kiedy miejsce ma sytuacja konkurencji. Strona lub świadek w tej sytuacji zeznaje nie z własnej inicjatywy i przejawia ustosunkowanie negatywne, przez co sędzia musi podjąć dodatkowy wysiłek, aby dotrzeć do prawdy. Podobna kwestia powstaje w sytuacjach konfliktowych, w których cele sędziego i strony lub świadka są wyraźnie rozbieżne, a przejawiane formy zachowań nabierają cech negatywnych, a nawet agresji. W powyższych sytuacjach sędzia musi posiadać zdolność panowania nad emocjami i pomimo trudności zewnętrznych dążyć do odkrycia prawdy w danej sprawie ${ }^{33}$.

Zebranie materiałów dowodowych prowadzi sędziego do kolejnego elementu rozpoznania sprawy, który należy ukazać od strony psychologicznej. Tym elementem jest ocena i wnioskowanie, które dokonuje się w umyśle sędziego pod wpływem konkretnych czynników. Sędziowskie wnioskowanie od strony psychologicznej określić można jako proces selekcji, interpretacji, zapamiętywania i wykorzystywania informacji zebranych w sprawie, koniecznych do wydawania sądów

\footnotetext{
32 Por. M. Przetacznikowa, G. MakieŁŁo-Jarża, Psychologia ogólna, Warszawa 1977, s. 135-136.

${ }^{33}$ Por. W. KoŁA Kowska, B. LACH, Psychologiczne determinanty zeznań świadków i osób składających wyjaśniania, Szczytno 2002, s. 16.
} 
i podejmowania decyzji ${ }^{34}$. Stąd wskazane jest, aby sędzia wyprowadzając wnioski w sprawie postępował według przyjętej przez siebie metody wnioskowania ${ }^{35}$.

Do przedstawienia wniosków w sprawie sędzia czerpie ze zgromadzonego materiału dowodowego, rozumując zgodnie z regułami logiki. Jednakże nie jest to jedyne źródło wiedzy sędziego. Psychologia wskazuje jako jedno ze źródeł poznania, komunikację niewerbalną. Podczas rozeznawania sprawy wiedza zdobyta przez sędziego poprzez własne obserwacje może okazać się bardzo istotna dla rozstrzygnięcia sprawy. Wiąże się to z faktem, że człowiek stanowi źródło wieloznacznych informacji, których interpretacja wymaga od sędziego uaktywnienia procesów myślenia ${ }^{36}$. Wnioskowanie jest więc gotowością poznawczych struktur umysłowych do wykonania pewnej czynności, którą w przypadku sędziego jest oceną dowodów zgromadzonych i przedstawionych w sprawie ${ }^{37}$.

Ostatnim elementem rozpoznawania sprawy, który warto zauważyć także od strony psychologicznej jest moment podejmowania przez sędziego decyzji rozstrzygającej w sprawie. Zebrane w sprawie dowody oraz proces myślowy określony mianem wnioskowania prowadzą sędziego do podjęcia rozstrzygnięcia problemu i uzewnętrznienia decyzji. Problem ujęty w formule sporu wytyczył u sędziego cel myślowy oraz bieg procesu myślenia, którego momentem finalnym jest podjęcie decyzji ${ }^{38}$.

W formułowaniu decyzji sądowej z punktu widzenia psychologii uczestniczą trzy podsystemy myślowe: orientacyjny, którego zadaniem jest odbieranie informacji, centralny, w którym dokonuje się przetworzenie informacji na fakty, modele i plany oraz wykonawczy, w którym dokonuje się moment decyzyjny ${ }^{39}$. Tym podsystemom

\footnotetext{
${ }^{34}$ Por. E. Arronson, T. Wilson, R. Akert, Psychologia społeczna, Serce i umyst, Poznań 1997, s. 127.

${ }^{35}$ Por. B. HoŁyst, Psychologia kryminalistyczna, Warszawa 2004, s. 1158.

${ }^{36}$ Por. J. Bruner, Poza dostarczone informacje, Warszawa 1978, s. 18.

${ }^{37}$ Por. B. HoŁyst, Psychologia kryminalistyczna, s. 913-914.

${ }^{38}$ Por. D. Czajka, Teoria sądzenia, Część I, Prawda sądowa, Warszawa 2005, s. 190.

${ }^{39}$ Por. T. Tomaszewski, Psychologia, Warszawa 1976, s. 522-526.
} 
odpowiadają trzy fazy podejmowania decyzji sędziowskich. Pierwsza z nich, faza poznawcza, dotyczy czynności gromadzenia, recypowania i przekształcania informacji, które dotyczą właściwej normy prawnej i jej znaczenia, a także faktów i zdarzeń rozpatrywanych przez sędziego. Następna faza dotyczy stricte procesów decyzyjnych i określa się ją mianem fazy konstruktywnej. Istotą tej fazy jest wartościowanie, czyli przypisanie przedmiotowi sprawy określonych cech, które w przypadku kanonicznego procesu małżeńskiego dotyczą ważności lub nieważności zawartego małżeństwa. Trzecia to faza komunikatywna, która odnosi się do procesów myślowych dotyczących już powziętej decyzji. Polega ona na uzewnętrznieniu decyzji sądu poprzez sformułowanie uzasadnienia i motywów powziętej decyzji. Jest to czynność sędziego, który musi w formie pisemnej przedstawić rozstrzygnięcie sprawy oraz jej argumenty i umotywowanie ${ }^{40}$.

W każdej z faz podejmowania decyzji sędziowskiej ważna jest także kontrola ukształtowanych w fazie poznawczej ocen oraz gotowość ich zmiany. Sędzia powinien być otwarty na nowe argumenty, które mogą zrodzić się w każdym momencie wnioskowania czy decydowania w sprawie. W przeciwnym wypadku grozi sędziemu wytworzenie tzw. efektu emocjonalnego zwanego również tendencyjnością psychologiczną ${ }^{41}$.

\section{Zakończenie}

Kanoniczny proces małżeński, który jest szeregiem ściśle uporządkowanych, określonych prawem i koniecznych do wykonania czynności, ma za zadanie rozpoznanie i rozstrzygnięcie, zgłoszonych przez strony postępowania roszczeń ${ }^{42}$. Roszczenie, które zostało określone w formule wątpliwości, zostaje poddane pod osąd sędziego kościelnego, który jest nie tylko wykonawcą normy prawnej, ale także

\footnotetext{
${ }^{40}$ Por. J. Kubiak, Psychologiczny mechanizm podejmowania decyzji sądowych w postępowaniu karnym, Zeszyty Naukowe Instytutu Badania Prawa Sądowego 1978, nr 8, s. 8.

${ }^{41}$ Por. T. Tomaszewski, Psychologia, Warszawa 1976, s. 394.

${ }^{42}$ Por. A. DzięGA, Strony sporu, s. 37.
} 
dokonuje jej interpretacji w perspektywie przedstawionych faktów i zdarzeń. Sędziowskie rozpoznanie sprawy jest procesem łączącym wymiar proceduralny, intelektualny, moralny i psychologiczny osoby sędziego. Wszystkie te elementy wpływają na ostateczne orzeczenie w sprawie. Stąd różnica zdań mogąca ujawnić się w wotach sędziowskich, jest dowodem nie na popełnienie błędów, lecz na osobiste zaangażowanie sędziego ze wszystkimi jego sferami poznawczymi. Sędziowskie rozstrzygnięcie zawarte w osobistym wotum, jest wypełnieniem roli sędziego w procesie kanonicznym oraz realizacją sądowniczej władzy w Kościele

\section{Vote of judges as an element constituting iudicium. Vote as an act of judges' power and its psychological conditioning}

The canonical matrimonial process, which is a series, defined by the law and necessary to perform the activities of the judge, whose task is to recognize and resolve the case. Therefore, a church judge is not only the executor of a legal norm, but also interprets it in the perspective of the presented facts and events. Judging the case is a process that combines the procedural, intellectual, moral and psychological aspects of the judge. The church judge, for his decision, not only possesses knowledge and experience, but also personal qualities and individual mental characteristics.

SŁOWA KLUCzOWE: proces kanoniczny; sędzia kościelny; decyzja sędziowska; cechy psychiczne

KEYwORDs: canonical process; church judge; judges' decision; mental features

\section{Nota o AUTORze}

Ks. DR Krzysztof OsKar PoKorski - prezbiter archidiecezji szczecińsko-kamieńskiej; doktor nauk prawnych; wiceoficjał w Sądzie Metropolitalnym Szczecińsko-Kamieńskim; wykładowca w Wyższej Szkole Administracji Publicznej w Szczecinie. 